\title{
In-Vivo Evaluation of Hexavalent Chromium Induced DNA Damage by Alkaline Comet Assay and Oxidative Stress in Catla catla
}

\author{
Kantha Deivi Arunachalam, \\ Sathesh Kumar Annamalai and Jaya Krishna Kuruva \\ Center for Environmental Nuclear Research, \\ Directorate of Research, SRM University, Chennai, Tamil Nadu, 603203, India
}

Received 2013-10-25; Revised 2014-01-14; Accepted 2014-01-15

\begin{abstract}
In the present study, the acute toxicity of Chromium in fingerlings of Catla catla, an Indian major carp, was evaluated with renewal bioassay method. In vivo studies were designed to assess the extent of Micronucleus Assay, Comet Assay under the exposure of common heavy-metal compounds, namely, Chromium Nitrate, using Catla catla $(2 \mathrm{n}=20)$, as a test model. The laboratory acclimatized fishes were divided into four groups. Group I served as positive control and the other three as exposed groups for three different time durations of 7,14 and 21 days and were subjected to uninterrupted sub lethal concentrations $(50 \%$ of $96 \mathrm{~h}$ $\mathrm{LC}_{50}$ ). The experiments were planned in such a way that fish from all the groups were sacrificed on the same day. The frequencies of micronuclei and bi-nuclei were evaluated comparatively in peripheral erythrocytes. As a result, it was observed that, the fishes and different tissues showed differential sensitivity to the heavy-metal treatment. A significant increase in the frequencies of micronucleated and binucleated cells and percentage increase in DNA tail $(\mathrm{p}<0.001)$ through Alkaline Comet Assay were observed after 21 days of exposure to chromium. Our results also showed decrease in enzyme Superoxide Dismutase (SOD) activity and increase in catalase enzyme due to increasing chromium concentration. The bio-concentration factor profiles of Chromium in Catla catla during sub lethal toxicity study was also calculated.
\end{abstract}

Keywords: Chromium, Micronucleus, Catla catla, Cytotoxicity, Comet Assay

\section{INTRODUCTION}

Aquatic ecosystem is the final sink for many chemicals used in industry and agriculture and has become a global problem (Adeogun and Chukwuka, 2012). When contaminants are released into the Aquatic Ecosystem, they finally get accumulated in the major aquatic organisms, almost invariably (Lavanya et al., 2011). Among all the contaminants, chromium is the one which are directly or indirectly released into aquatic ecosystem (Gheju, 2011). The influx of this global environmental toxicant into aquatic ecosystems from naturally occurring and anthropogenic sources is a serious problem throughout the world (Kumar et al., 2009). Chromium is a common contaminant in surface water and groundwater because it is used widely in electroplating and other industries and occurs naturally at high concentrations in ultramafic rocks. Under oxidizing conditions, $\mathrm{Cr}$ is highly soluble and mobile as the $\mathrm{Cr}$ (VI) anions chromate $\left(\mathrm{CrO}_{4}{ }^{2-}\right)$ and bichromate $\left(\mathrm{HCrO}^{4-}\right)$ (Ellis et al., 2002). The health effects and toxicity or carcinogenicity of chromium are mainly related to the oxidation state of the metal at exposure. Trivalent (Cr[III]) and Hexavalent (Cr[VI]) compounds are thought to be the most biologically significant, (Jomova and Valko, 2011).

Hexavalent chromium is widely used in many industrial processes such as electroplating, wood preservation. The remediation of chromium contaminated sites poses several unique challenges. Ranipet regions of Tamil Nadu, a Province in India, have Leather Tanneries Corresponding Author: Kantha Deivi Arunachalam, Center for Environmental Nuclear Research, Directorate of Research, SRM University, Chennai, Tamil Nadu, 603203, India Tel: 044-27417144; Fax: 044-27417146 
located in an industrial development area, from which treated and untreated effluents are released into Palar river. The granitic formation in the northern part of Palar River catchment has the high infiltration rates and results in fast migration of the contamination to the water table. The Chromium levels in groundwater of these areas were found up to $275 \mathrm{mg} \mathrm{L}^{-1}$ as reported by (Rao et al., 2011). Taking the Paler River catchment into consideration to access the genotoxic effects of major Indian carp Catla catla is chosen for our study. Ingestion of large amounts of chromium can lead to severe respiratory,cardiovascular, gastrointestinal, hepatic and renal damage and potentially death (Fatemi et al., 2013).

Many studies have directed their attention to asses the effect of chromium in the tannery and electrochemical works. For example, the genetic alterations in direct and indirect exposures of Hexavalent Chromium $[\mathrm{Cr}(\mathrm{VI})]$ in leather tanning industry workers have been reported by (Balachandar et al., 2010), while, the indirect effect has been studied by dietary uptake of chromium by fishes. Fish are at the top of the aquatic food chain and normal metabolism of fish may accumulate large amounts of certain metals from water, food, or sediment. However, like essential metals, nonessential metals are also taken up by fish and gets accumulated in their tissues (Y1lmaz et al., 2010). As fish fauna serves as a food source for humans, it is essential to know the impact of water pollution on these organisms. Any change in the natural conditions of aquatic medium causes several physiological adjustments in fish (Garg et al., 2009). Fish has attracted much attention in the biomonitoring of water pollution because of its special biological characters such as relatively big body size, long life cycle, easy to raise. More importantly, fish species are at the top of the aquatic food chain and may directly affect the health of humans, which makes it more significance for the biomonitoring using fish. (Foster et al., 2012; Zhou et al., 2008).

Therefore, to provide data supporting the usefulness of freshwater fish as indicators of heavy metal pollution, it has been proposed in the present study, to examine the bioaccumulation and genotoxic evaluation of chromium in the selected organs of freshwater fingerlings Catla catla. In the current investigation, the freshwater fingerlings Catla catla was used, because it is one of the most common Indian carp and withstands a wide range of experimental conditions. It occurs in the principle rivers of India and is a moderately fast growing freshwater major carp. In addition, it is of great commercial importance and is renowned for its taste.

The DNA damage was evaluated by Micronucleus (MN) and comet assays which are the two sensitive, rapid and extensively used tools for detecting the mutagenic and genotoxic effects of chemicals in the environment, since Micronucleus (MN) assay is an easy and ideal monitoring system that uses aquatic organisms to assess the Genotoxicity of water in the field and in the laboratory (Ali et al., 2008a; 2009; Bucker et al., 2012). Muid et al. (2012) has pointed out that the comet assay is considered a suitable and rapid test for DNA-damaging potential in environmental and biomonitoring studies. Research reports indicate that it can be applicable to freshwater and marine fishes and that gill cells are more sensitive than the hematopoietic cells to micronucleus inducing agents which has been reported by most of the researchers (Al-Sabti and Metcalfe, 1995; Cavas et al., 2005; Fontanetti et al., 2010; Palus et al., 2003).

The concern over aquatic pollution has recently gained importance; thus, monitoring of genotoxic effects is of major importance. The genotoxic effects of environmental pollutants can be monitored using a broad range of both in vitro and in-vivo biomarker assays, while the comet assay is gaining popularity and acceptance over other assays since its advantages include its sensitivity for detecting low levels of DNA damage (0.1 DNA break $/ 10^{9}$ Daltons) (Ali et al., 2008b) To quantify DNA lesions in individual cells for environmental monitoring was also reported (De Andrade et al., 2004). Also many researchers also conducted the pilot study to access the genotoxic efface under the laboratory scale (Emmanouil et al., 2006; Hartmann, 1997; Heuser et al., 2002).

In the present study, we aim to investigate the effects of exposure to sublethal concentrations of chromium in freshwater fish Catla catla, under in-vivo conditions. The mutagenic and genotoxic effects of chromium exposure was assessed using $\mathrm{MN}$ assay and comet assay, by monitoring the frequencies of binucleated cells, as an indicator of cytotoxicity, were in addition to the micronuclei. Micronucleus and binucleus frequencies in erythrocytes were analyzed, including the single-stranded DNA break by comet assay analysis. Further, the response of Catalase and Superoxide Dismutase (SOD) activity in the tissues was determined to get a clear outline of the antioxidant stress potential. This data could provide a useful database for future investigations of pollutant effects in freshwater fish in aquatic environments.

\section{MATERIALS AND METHODS}

\subsection{Experimental Fish and Chemicals}

Single breed fingerling of Catla catla with a mean length of about $6.00 \pm 2.00 \mathrm{cms}$ and an average weight of about $10.00 \pm 2.00 \mathrm{~g}$ were procured from commercial fish seed hatchery and safely transported to the laboratory in 
syntax tanks containing oxygenated water. Fish were stocked in large aquarium tanks disinfected with potassium permanganate to prevent fungal infection and washed thoroughly prior to introduction of fish (Ali et al., 2009). The specimens were given prophylactic treatment by bathing them twice in $0.05 \%$ potassium permanganate $\left(\mathrm{KMnO}_{4}\right)$ solution for 2 min to avoid any dermal infections. The fishes were then acclimatized for one month under laboratory condition (Hernández et al., 2006). The faucal matter and other waste materials were siphoned off daily to reduce ammonia content in water (Company et al., 2010). Fish were fed at libitum with rice bran and groundnut oil cake once a day in their experimental tanks. The same food was used for controls and exposed fish and it was always consumed rapidly so soaking of the food by the exposure water was limited (Eyckmans et al., 2011). Water quality was checked every day before and during the exposure. The physical and chemical parameters of the tank water, when the fish were placed in it, are shown in Table 1, in comparison with the water of the Krishna River, a major river in South India. Chromium nitrate (analytical grade) used in the present study was purchased from Merck specialties Pvt Ltd, Mumbai, India.

\subsection{Determination of Sublethal Concentrations}

Preliminary series of short-term $(96 \mathrm{~h})$ static toxicity tests were run to determine the median Lethal Concentrations of chromium $\left(\mathrm{LC}_{50}\right)$ in Catla catla. They were estimated by both the Arithmetic-Karber method (Dede and Kaglo, 2001) and Finney’s Probit analysis method described by (Finney, 1971).

Experiments were performed in 1251 glass aquaria with 1001 experimental water, by introducing 35 fish in each tank. Water was continuously aerated, with light and darkness regime at 14 and $10 \mathrm{~h}$ respectively. The physiochemical parameters of the experimental tank were maintained within the limits as described in Table 1. The Physiochemical parametrs are maintained in comparision of the Krishna river, Nagarjuna sagar Dam. Prior to the determination of the sublethal concentration, the fishes were subdivided into groups consisting of 35 Nos (Hernández et al., 2006). The acclimatized animals were each exposed to one of the following nominal Chromium concentrations: 0 (control), 30, 60, 90 and $150 \mathrm{mg} \mathrm{L}^{-1}$ total Chromium, obtained after range finding test and the experiment was set in triplicate to obtain the $96 \mathrm{~h} \mathrm{LC}_{50}$ value of the test chemical for the species. Mortality and abnormal behavioral responses were recorded every $24 \mathrm{~h}$, until 96 h (Company et al., 2010). During the experiment, dead fish were removed immediately because such mortality in static bioassays may deplete the DO, affecting tolerance limits (Alkassasbeh et al., 2009).
Table 1. Physico-chemical parameters of experimental water

\begin{tabular}{ll}
\hline Physico-chemical parameters & Range \\
\hline Temperature & $27 \pm 3^{\circ} \mathrm{C}$ \\
pH & $7.8 \pm 0.5$ \\
Dissolved oxygen & $6.73 \pm 0.20 \mathrm{mg} \mathrm{L}^{-1}$ \\
Hardness of water & $145.66 \pm 8.14 \mathrm{mg} \mathrm{L}^{-1}$ \\
Turbidity & $2.66 \pm 0.57 \mathrm{NTU}^{-1}$ \\
Total dissolved solids & $254 \pm 11.53 \mathrm{mg} \mathrm{L}^{-1}$ \\
\hline
\end{tabular}

The results are expressed as mean $\pm \mathrm{SD}$

\subsection{Experimental Design for Acute Toxicity Tests}

The fish specimens were exposed to sublethal test concentration of chromium nitrate in a semi-static system with the change of test water on every alternate day to maintain the concentration of the chemical. Group I $(\mathrm{n}=$ 20) served as positive control and the other three as exposed groups $(\mathrm{n}=20)$ for three different time durations of 7, 14 and 21 days and were subjected to sublethal concentrations $\left(50 \%\right.$ of $96 \mathrm{~h} \mathrm{LC}_{50}$ ) (Quinn et al., 2006; Yadav and Trivedi, 2009). All the experiments were performed in duplicates. Chromium nitrate was dissolved in deionized water and a clear solution was obtained by adding few drops of acetic acid. The exposure was continued up to 21 days. Blood and tissue sampling, as described below, was done at the intervals of 0 th, 7 th, 14 th and 21 st days at the rate of 20 fish per interval.

\subsection{Sampling and Analysis}

Sampling of fish tissue was done at the intervals of 0th, 7th, 14th and 21st days from all tanks. At the end of $24 \mathrm{~h}$ of exposure, at least six fish for each of the four groups were anesthetized with benzocaine $(0.1 \mathrm{~g}$ $\mathrm{L}^{-1}$ ) and blood was collected from the caudal vein, using heparin-coated syringes (Bucker et al., 2012; Heuser et al., 2002). On each sampling day, the whole blood was collected and immediately processed for Micronuclei assay as described below. About $0.5 \mathrm{~mL}$ of diluted blood was added to an isotonic solution $(10 \mathrm{~mL})$ for further dilution in dark or dim light to prevent occurrence of any further additional DNA damage.

\subsection{Micronucleus (MN) Assay and Scoring Criteria}

The MN test was performed according to the methods of (Bolognesi and Hayashi, 2011), with some minor modifications. Blood samples were collected by cardiac puncture using the cold hypodermic micro syringes prerinsed with heparin (anticoagulant). The blood samples were immediately smeared onto precleaned glass slides, air dried overnight and then 
fixed in absolute methanol for 15 min. Each slide was stained with 5\% Giemsa solution (Medox Biotech India Pvt. Ltd., Chennai) for $20 \mathrm{~min}$. At least 1,500 erythrocytes for each specimen were identified, counted and scored microscopically under 1,000 X in Carl Zeiss microscope (Mortazavi et al., 2005). The main criteria for scoring the Micronucleus (MN) were based on those of Al-Sabti and Matcalfe (1995) considering the absence of connections with the main nucleus, similar coloration and a size of between $1 / 10$ to $1 / 30$ of the size of the main nucleus, since for most fish, chromosomes are much smaller than mammalian chromosomes, as pointed out by (Schmid, 1975). The nuclear abnormalities observed were classified into five categories, adapting the classification proposed by (Ayllon and Garcia-Vazquez, 2000): (a) Micronuclei; (b) Binucleated nucleus-two completely separated nuclei in the same erythrocyte's cytoplasm; (c) Lobed nucleus-evaginations of the nuclear envelope of different sizes; (d) Notched nucleus-having a noticeable depression into the nucleus that does not contain nuclear material and (e) Other Nuclear Abnormalities-all the other types of nuclear morphological alterations found in the nuclei that could not be fitted under the previous four categories.

\subsection{Comet Assay}

The alkaline comet assay was performed as described briefly, as follows; $100 \mu \mathrm{L}$ of cell suspension was mixed with $200 \mu \mathrm{L}$ of $2 \%$ low melting temperature agarose at $37^{\circ} \mathrm{C}$ and then placed on a slide precoated with thin layer of $0.5 \%$ normal melting agarose. The cell suspension was immediately covered with a cover glass to obtain a uniform layer and the slides were kept at $4^{\circ} \mathrm{C}$ for five min, to allow solidification of the agarose (Rojas et al., 1999). The gel was allowed to solidify by keeping the slide in a steel tray on ice for a minimum period of three minutes. The coverslip was removed and a final layer of $0.5 \%$ Low Melting Point (LMP) agarose $(100 \mu \mathrm{L})$ was placed on the slide and covered with a cover slip (Tice et al., 2000).

After removing the cover glass, the cells were lysed in a lysing solution $(2.5 \mathrm{M} \mathrm{NaCl}, 100 \mathrm{mM}$ EDTA, $10 \mathrm{mM}$ Tris, $1 \%$ Triton $\mathrm{X}-100, \mathrm{pH} 10$ ) for one hour. After washing in redistilled water, the slides were placed in a horizontal gel electrophoresis chamber. The chamber was filled with cold electrophoretic buffer (1mM EDTA, $300 \mathrm{mM} \mathrm{NaOH}, \mathrm{pH} 13$ ) and slides were kept at $4{ }^{\circ} \mathrm{C}$ for 40 min to allow the DNA to unwind. Electrophoresis was performed for $25 \mathrm{~min}(1 \mathrm{~V} / \mathrm{cm}, 300 \mathrm{~mA})$. After electrophoresis, the slides were washed three times with neutralization buffer (0.4M Tris, $\mathrm{pH} 7.5)$. All preparative steps were conducted in yellow light to prevent occurance of additional DNA damage (Avishai et al., 2003; Tice et al., 2000; Velma and Tchounwou, 2010).

The slides were stained with Ethidium Bromide. Air-dried slides were immersed for five minutes in cold water and then stained for five minutes with $80 \mu \mathrm{L}$ EtBr $\left(20 \mu \mathrm{g} \mathrm{mL}^{-1}\right)$ (Cavallo et al., 2009; Kim et al., 2002). The slides were rinsed in cold water to remove excess stain and covered with a coverslip and analyzed with a fluorescence microscope (NIKON Eclipse 400) equipped with a CCD-4230A video camera. The nuclei were analyzed by use of a fluorescence microscope. For EtBr, a BP 546/10 nm excitation filter and a $590 \mathrm{~nm}$ emission filter were used. For each slide, 25 randomly chosen nuclei were analyzed. Three slides were evaluated per treatment and was repeated twice. From the repeated experiments, the averaged median percentage of tail DNA as the primary measure of DNA migration was calculated for each treatment group. Digital images were acquired and analyzed by the CASP software (Anitha et al., 2000; Emmanouil et al., 2006).

\subsection{Catalase (CAT) Activity}

The activity of catalase (CAT) in the liver was determined spectrophotometrically, at wavelength of 570 nm (Uv-Vis, 3000+, lab India Pvt. Ltd., India), according to the method of Sinha (1972) and was expressed in $\mathrm{ml}$ mol of decomposed hydrogen peroxide per sec per gram of tissues wet wt. Sinha (1972) tissue samples were homogenized in 10 volume of ice-cold 0.1 phosphate buffers, $\mathrm{pH} 7.0$ and centrifuged for $20 \mathrm{~min}$ at $4{ }^{\circ} \mathrm{C}$ and $15,000 \mathrm{~g}$. The supernatant was used for CAT. The activity of catalase was determined spectrophotometrically, by measuring the decrease in the absorbance of hydrogen peroxide at $240 \mathrm{~nm}$, with a specific absorption coefficient of $0.0392 \mathrm{~cm}^{2} \mu \mathrm{moL}$ $\mathrm{H}_{2} \mathrm{O}_{2}{ }^{-1}$. $2.5 \mathrm{~mL}$ of substrate made up of $10 \mathrm{mM}$ hydrogen peroxide in a $50 \mathrm{mM}$ phosphate buffer of $\mathrm{pH}$ 7.0 was added onto $2.5 \mathrm{mg}$ of immobilized CAT preparation. Reaction was carried out at $25^{\circ} \mathrm{C}$ for $2 \mathrm{~min}$ and stopped by adding $0.5 \mathrm{~mL}$ of $1.0 \mathrm{M} \mathrm{HCl}$. One unit of activity is defined as the decomposition of $1 \mu \mathrm{moL}$ hydrogen peroxide per minute at $25^{\circ} \mathrm{C}$ and $\mathrm{pH} 7.0$ (Sayeed et al., 2003; Sun et al., 2006).

\subsection{Superoxide Dismutase (SOD) Activity}

The activity of Superoxide Dismutase (SOD) was determined spectrophotometrically at wavelength of 
$480 \mathrm{~nm}$ by epinephrine method according to Sun et al. (2006). SOD was determined spectrophotometrically in Liver, Muscle Tissue and Gill samples by measuring the inhibition of the ratio of autocatalytic adrenochrome formation at $480 \mathrm{~nm}$ in a reaction medium containing $1 \mathrm{mM}$ adrenaline and $50 \mathrm{mM}$ glycine $(\mathrm{pH}$ 10.2). This reaction was conducted at a constant temperature of $30^{\circ} \mathrm{C}$ for $3 \mathrm{~min}$. Enzyme activity is expressed as superoxide dismutase units per gram of protein. One unit is defined as the amount of enzymes that inhibits the ratio of adrenochrome formation by $50 \%$ (Sun et al., 2006; Velma and Tchounwou, 2010).

\subsection{Metal Analysis in Tissue Samples}

The muscle tissues were washed with distilled water, dried to a constant weight at $60^{\circ} \mathrm{C}$ for $48 \mathrm{~h}$ until constant weight is obtained. Dried samples were homogenized, packed in small pre-cleaned polyethylene bottles and kept at $-20^{\circ} \mathrm{C}$ until analysis. All reagents were of analytical grade. Unless otherwise stated, double deionized water was used for all dilutions. The dried fish samples were placed in a high form porcelain crucible and kept in the muffle furnace. The furnace temperature was slowly increased to $100^{\circ} \mathrm{C}$ in two hours. The samples were ashed at about $450^{\circ} \mathrm{C}$ for one night, until a white or grey ash residue was obtained. About $5 \mathrm{~g}$ of the ash samples were used for digestion. The samples were digested with $25 \mathrm{~mL}$ of Nitric Acid $(70 \% \mathrm{~V} / \mathrm{V})$ and 5 $\mathrm{mL}$ of sulphuric acid $(98 \% \mathrm{~V} / \mathrm{V})$ and $5 \mathrm{~mL}$ perchloric acid $(\% \mathrm{~V} / \mathrm{V})$ at $110^{\circ} \mathrm{C}$. The Formation of the milky white precipitate confirms the complete digestion of sample. The sample is then filtered in Whatman No42 filter paper and made upto $50 \mathrm{~mL}$ with double deionized water (Al-Yousuf et al., 2000; Mendil et al., 2010; Oyoo-Okoth et al., 2010). The samples were analyzed for heavy metals using Inductively Coupled Plasma Optical Emission Spectrometry (ICPOES) at Sophisticated Analytical Instrument Facility (SAIF), the Indian Institute of Technology, Madras.

\subsection{Bio Concentration Factor (BCF)}

The Bio concentration factor is the biological sequestering of a substance at a higher concentration than at which it occurs in the surrounding environment or medium. The bioaccumulation factor is the ratio of the contaminant in an organism to the concentration in the surrounding environment at a steady state, where the organism can take the contaminant through ingestion with its food as well as through direct content.

Bioconcentration factors between the fish tissues and the water were calculated, using the mean metal concentration in each tissue and the corresponding metal concentration in simulated water. Bioconcentration Factor (BCF) is defined as the ratio of the concentration of a specific heavy metal in the organism to the concentration of the metal in the water in which the fish lives (Sun et al., 2006). The BCF was calculated using the formula 1 as described below Equation (1):

$\mathrm{BCF}=\frac{\mathrm{C}_{\mathrm{f}}}{\mathrm{C}_{\mathrm{w}}}$

where, $\mathrm{C}_{\mathrm{f}}$ and $\mathrm{C}_{\mathrm{w}}$ are the concentrations of metal in fish and water respectively, expressed in the same units $(\mathrm{mg} / \mathrm{kg}$ and $\mathrm{mg} / \mathrm{L})$. BCF will, hence, be a simple number, without any units.

\subsection{Statistical Analysis}

One-way Analysis of Variance (ANOVA) was applied to determine significant differences in the results of various groups. P-Values $<0.001$ were considered significant. The data obtained from analytical methods were treated statistically using SPSS software (version 17.0 for windows). Descriptive data analysis was performed, including the calculation of mean, SD.

\section{RESULTS AND DISCUSSION}

The data obtained from acute toxicity test of waterborn chromium for Catla catla revealed that chromium toxicity increased with increasing concentration and with exposure time. The number of dead fish in relation to the chromium concentrations (20,60, $\left.100 \mathrm{mg} \mathrm{L}^{-1}\right)$ were assessed and counted during the exposure period and were removed. No mortality was observed during the $96 \mathrm{~h}$ at control $(0.0$ $\mathrm{mg} \mathrm{Cr} \mathrm{L} \mathrm{L}^{-1}$ ) and $100 \%$ mortality rate was observed only at $100 \mathrm{mg} \mathrm{L}^{-1}$ (Table 2).

The fish exposed to 20 and $60 \mathrm{mg} \mathrm{L}^{-1}$ chromium showed abnormal behavior like erratic swimming and loss of equilibrium. The exposed fish swam to surface more often than the control fish. Neither mortality nor any visible changes in behavior were viewed in the control group. Summary of the different behavioral changes observed due to chromium exposure is presented in Table 3. 
Table 2. $\mathrm{LC}_{50}$ determination based on arithmetic method of karber

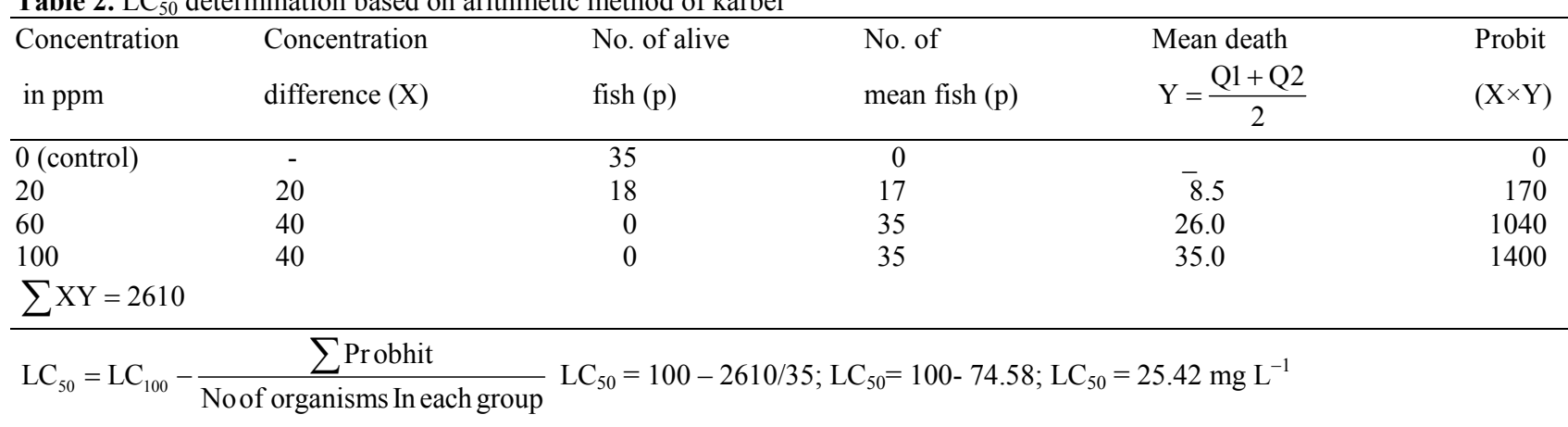

Table 3. Determination of $96 \mathrm{~h} \mathrm{LC}_{50}$ Value using Finney's Probit analysis (1964)

\begin{tabular}{lllccc}
\hline Conc. $(\mathrm{mg} / \mathrm{L})$ & Log $($ Conc.) & No. of fish alive $(96 \mathrm{~h})$ & No. of fish dead $(96 \mathrm{~h})$ & Mortality $(\%)$ & Probit \\
\hline 0 & 0.00 & 35 & 0 & 0.0 & - \\
74.6 & 1.87 & 18 & 17 & 48.5 & 4.95 \\
223.7 & 2.35 & 0 & 35 & 100.0 & 7.37 \\
373 & 2.57 & 0 & 35 & 100.0 & 7.37 \\
\hline
\end{tabular}

The relationship between the chromium concentration and the mortality rate of Catla catla for determination of $\mathrm{LC}_{50}$ value was determined according to Finney's Probit Analysis and the results are shown in Fig. 1. A dosedependent increase and time dependent decrease were observed in mortality rate until $96 \mathrm{~h}$. The $\mathrm{LC}_{50}$ value of chromium was determined as $25.42 \mathrm{mg} \mathrm{L}^{-1}$ for Catla catla by Arithmetic Method of Karber (Dede and Kaglo, 2001; Mishra and Mohanty, 2008) and Finney's Probit analysis (Finney, 1971). The mean 96-h $\mathrm{LC}_{50}$ value with 95\% confidence limits for Catla catla by Finney's probit analysis was found to be $25.42 \mathrm{mg} \mathrm{L}^{-1}$ as shown in Table 3. This value was estimated to be $25.42 \mathrm{mg} \mathrm{L}^{-1}$ with the Karber's method (Table 2). The two methods are in good agreement and this suggests that the water-born chromium is definitely a toxic heavy metal to Catla catla.

Based on the $96 \mathrm{~h} \mathrm{LC}_{50}$ value, the sublethal concentration $\left(1 / 2\right.$ of $96 \mathrm{~h} \mathrm{LC}_{50}$ value $\left.=25.42 \mathrm{mg} \mathrm{L}^{-1}\right)$ of chromium were estimated. This value was used for the bioconcentration and genotoxicity studies. The exposed fish swam to surface more often than the control fish. Neither mortality nor any visible changes in behavior were observed in the control group. The hypertrophy and hyperplasia of the gill epithelial cells were absorbed as the gills were swollen compared to the Control fish (Quinn et al., 2006).

\subsection{Accumulation of Chromium in Catla Catla}

The sublethal concentration was used for this study and therefore, no mortality was recorded during the experimental period for all treatment groups studied. The increased levels of accumulation during the exposure period suggested a rather rapid absorption of this metal.
Similar results have been reported in freshwater isopods exposed to $\mathrm{Cu}, \mathrm{Pb}$ and $\mathrm{Zn}$ (Palaniappan and Karthikeyan, 2009). In the case of bioaccumulation of chromium in the muscle, the accumulation pattern varies with the degree of concentration of the toxicants. Occasionally, fish exposed to Chromium showed vertical and downward swimming patterns, swimming near the water surface, drowsy and erratic swimming and loss of schooling behavior.

During the sublethal toxicity studies the fishes were exposed to $1 / 2$ of $\mathrm{LC}_{50}$ concentration. As the days of exposure increased, the chromium concentration in the fish tissues increased gradually. As the exposure period continued till 21 days. The accumulation of chromium was maximum within 7 days of exposure $\left(9.68 \mathrm{mg} \mathrm{kg}^{-1}\right)$ and after 7 days the chromium is slowly bioaccumulated in the tissues. The maximum accumulation of the chromium was observed on the $21 \mathrm{st}$ day of exposure $\left(11.25 \mathrm{mg} \mathrm{kg}^{-1}\right)$. The pattern of accumulation of chromium in Catla catla during sublethal toxicity studies were shown in the Fig. 2.

\subsection{Genotoxicity of Chromium in Catla Catla by Micronucleus Assay}

Micronucleus was encountered in fish subjected to chromium accumulation. Induction of micronuclei showed a remarkable increase with increased exposure time, when compared with the control. The results suggested that the incidence of micronuclei induction was not dose dependent. In contrast, the group treated with Chromium did not show significant difference in micronuclei frequencies with respect to the control group, although differences between frequencies of the treated and control groups for the other nuclear lesions were highly significant (Anbumani and Mohankumar, 2012). 


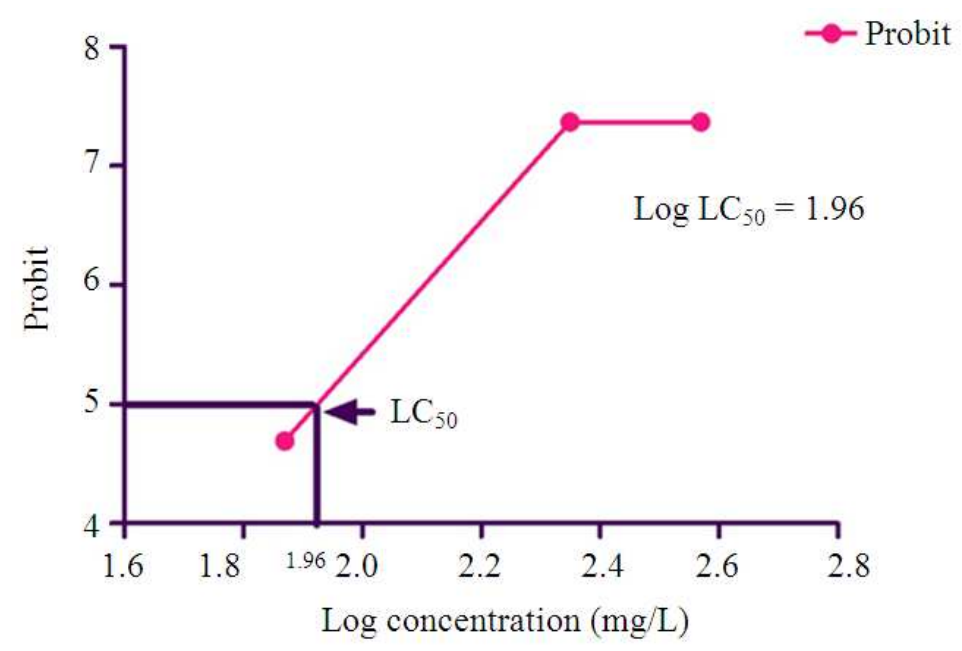

Fig. 1. Probit analysis graph for determining $96 \mathrm{~h} \mathrm{LC}_{50}$ by Finney probit method

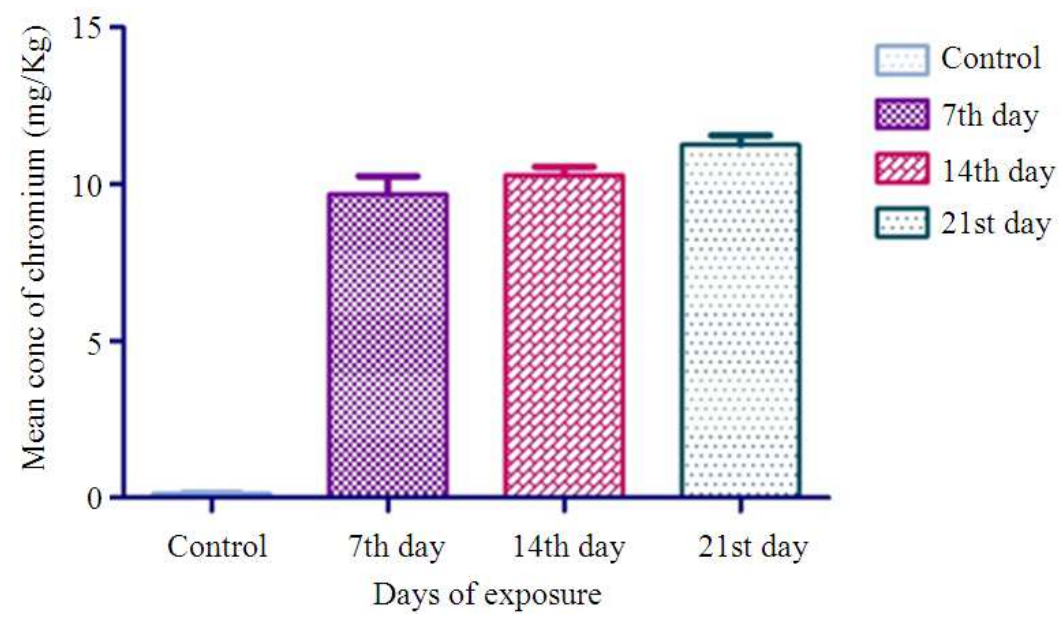

Fig. 2. Exposure by waterborne chromium by Catla catla each point represents a mean value and standard deviation of three replicates

Our studies for determination of sublethal concentration, short-term exposure periods ranging between 24 and $96 \mathrm{~h}$ were reported to be enough to induce micronuclei and erythrocytes had been reported to be a sensitive biomarker of Genotoxicity (Results not shown). However, results of long-term exposure studies in fish revealed that micronucleus frequencies in erythrocyte's increases as the days of exposure increased as shown in Table 4. Apart from $\mathrm{MN}$, other nuclear anomalies like deformed nucleus, nuclear bud and vacuolated nucleus, binucleated cells were observed at sublethal exposure. Similar observations from our results are in agreement with other studies (Klobucar et al., 2012; Yadav and Trivedi, 2009).
The micronucleus formation in the erythrocytes requires cell division. This difference can be explained by a lower mitotic rate caused by a lower average temperature and by older fish (Polard et al., 2011).

\subsection{Alkaline Comet Assay}

About 100 cells were selected randomly for each sample, i.e., 50 cells were selected from each of the two replicate slides. The observation of cells was made at $400 \times$ magnification using a fluorescence microscope with the mean tail length and mean tail moment serving as the indicators. The Observed DNA damage in erythrocytes of Catla catla exposed to chromium on different days of treatment is shown in Fig. 3. 
Kantha Deivi Arunachalam et al. / American Journal of Environmental Science 9 (6): 470-482, 2013

Table 4. Nuclear abnormalities in peripheral erythrocytes of catla catla exposed to sublethal concentration of chromium

\begin{tabular}{lllll}
\hline Days of exposure & Micro-nucleated cells & Bi-nucleated cells & Lobed & Other nuclear abnormalities \\
\hline 0th day & $1.67 \pm 0.57$ & $3.34 \pm 2.51$ & $1.11 \pm 0.21$ & 0 \\
7th day & $9.34 \pm 1.52$ & $37.6 \pm 16.04$ & $15.21 \pm 1.82$ & $3.0 \pm 0.52$ \\
14th day & $71.0 \pm 5.56$ & $73.7 \pm 5.50$ & $89.4 \pm 3.23$ & $22.1 \pm 1.26$ \\
21st day & $126 \pm 7.21$ & $83.0 \pm 5.56$ & $142 \pm 2.11$ & $36 \pm 1.52$ \\
\hline
\end{tabular}

The frequencies of MN data were analyzed by the ANOVA Kruskall-Wallis and Mann-Whitney tests. The results are expressed as mean \pm SD and Fold increase of $\%$ of nucleated cells in comparison with concurrent controls, $p<0.001$

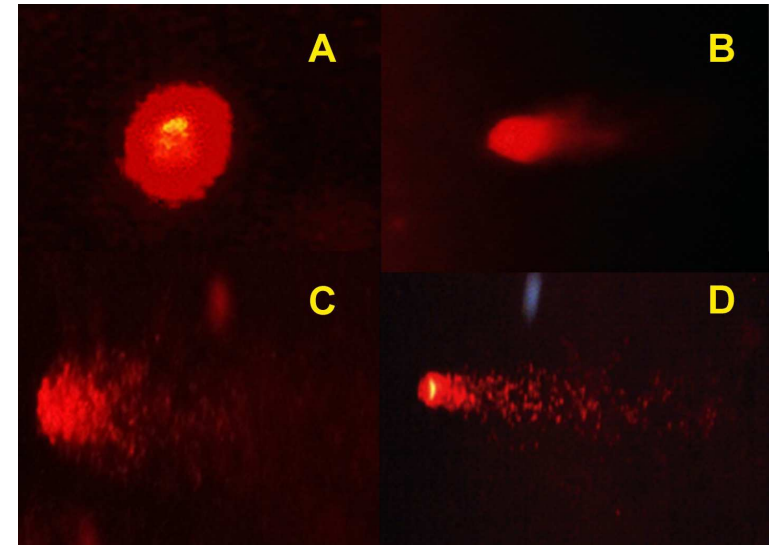

Fig. 3. Comet assay images of DNA damage profile in Catla catla in erythrocyte cells exposed to Chromium on different days of exposure A- Control Comet, B- $7^{\text {th }}$ Day Comet, C- $14^{\text {th }}$ Day Comet, D- $21^{\text {st }}$ Day Comet

The highest DNA damage was observed at 21 days of exposure for all treatment groups; there was a bioconcentration increase in percentage of DNA damage with chemical exposure. The damage was measured by using the tail moment as the parameter of assessment. The percentage of tail DNA as the primary measure of DNA migration was calculated for each treatment group by the Comet Assay Software Project (CASP) software and is shown in Fig. 4.

The DNA damage was measured as \% tail DNA in the erythrocytes in the control as well as exposed groups as shown in Fig. 5. The percentage of tail DNA was significantly $(\mathrm{p}<0.01)$ increased with the days of exposure increasing the concentration of chromium. However, inducting DNA damage was tissue specific and showed significantly $(\mathrm{p}<0.01)$ higher DNA damage. The highest DNA damage was observed in 21 days of exposure. $15 \%$ of tail DNA was observed at 7 days of exposure. There was a general increase in the DNA damage values with increased exposure time.
Olive Tail Movement is determined with the distance between the head and centers of gravity of DNA in the tail and is shown in Fig. 6. Although Olive Tail Moment appeared to be the most statistically significant measurement, it provides an estimate of DNA damage in arbitrary units. The Olive Tail Movement is similar to the percentage of the Tail DNA. Since it is wellknown that distinct image-analysis systems give different values for OTM (Kumaravel and Jha, 2006).

Similar mechanism which supports our results have been reported by Quievryn et al. (2003). These results indicate that ascorbate is the most efficient biological reductant of $\mathrm{Cr}$ (VI) in cells under in-vivo conditions and plays a dual role in $\mathrm{Cr}$ (VI) toxicity: Protectiveantioxidant outside and pro oxidative inside the cell. In fact, reactions utilizing ascorbate in the reduction of chromium (VI) inside the cells generate high levels of chromium-DNA adducts and produce mutation-inducing DNA damage (Quievryn et al., 2003).

From the comet assay results we can also conclude that the mechanism of the DNA damage can be described as follows: The $\mathrm{Cr}$ (VI) enters the system either by ingestion or by absorption as an oxyanion. The absorbed chromium is metabolic reduction to $\mathrm{Cr}(\mathrm{V}), \mathrm{Cr}$ (IV) and to the final reduced trivalent (III) form. These reduced forms have been shown to induce a wide range of genomic DNA damage, which make chromium to DNA replication inhibition (Nickens et al., 2010).

\subsection{SOD and Catalase}

The results as shown in Table 5 shows, the decreased activity of SOD in tissues of Catla catla during acute exposure to chromium, which indicates the presence of ROS-induced peroxidation, which leads to destroy RBC membrane. The results of our present experiments show decrease of superoxide dismutase and catalase enzyme in several samples. The decrease in erythrocyte SOD activity suggests a lower formation rate of intracellular $\mathrm{H}_{2} \mathrm{O}_{2}$. Similar decrease patterns was also observed by other researchers (Emmanouil et al., 2006; Kubrak et al., 2011). 
Kantha Deivi Arunachalam et al. / American Journal of Environmental Science 9 (6): 470-482, 2013

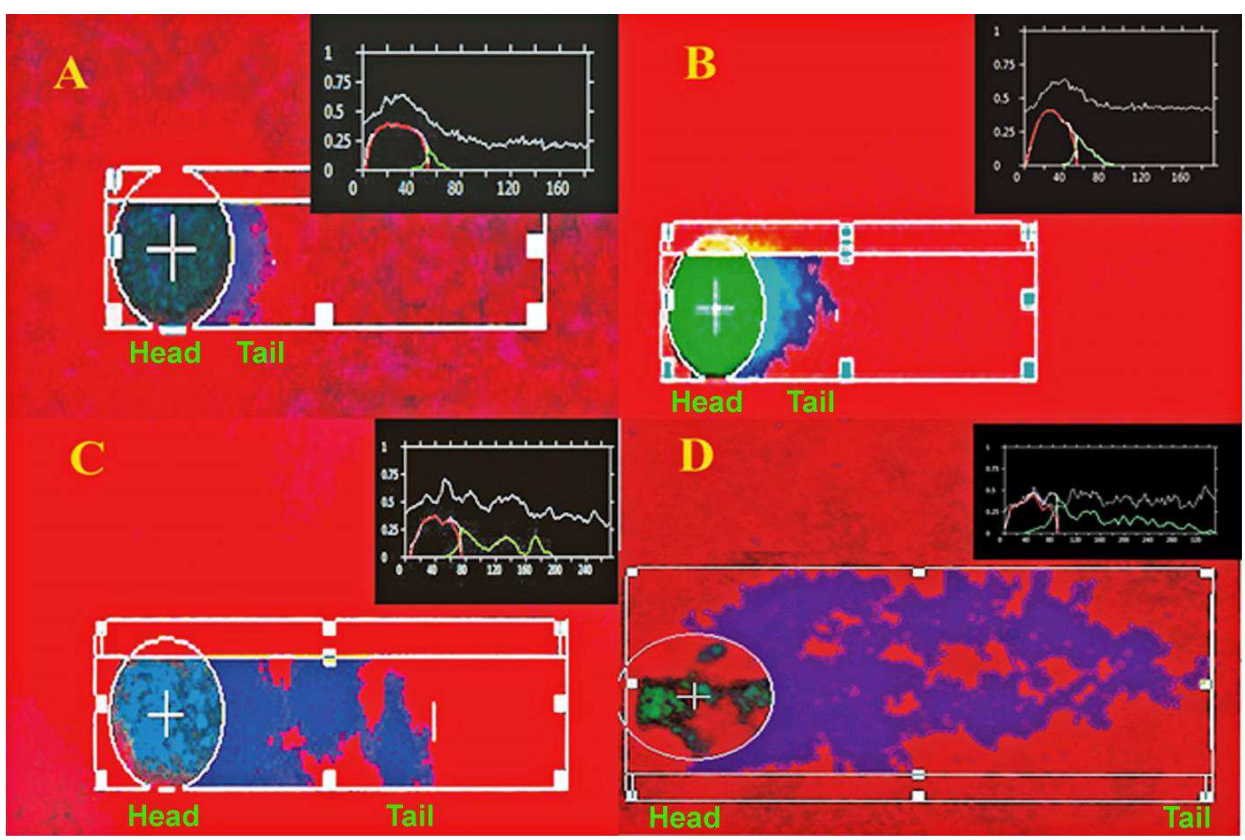

Fig. 4. Comet images of control and damaged cells and the insert with in the images represents the percentage of tail DNA and Olive tail movement A-Control cells, B-7th Days treated cells C-14th day treated cells D-21st Day Treated Cells

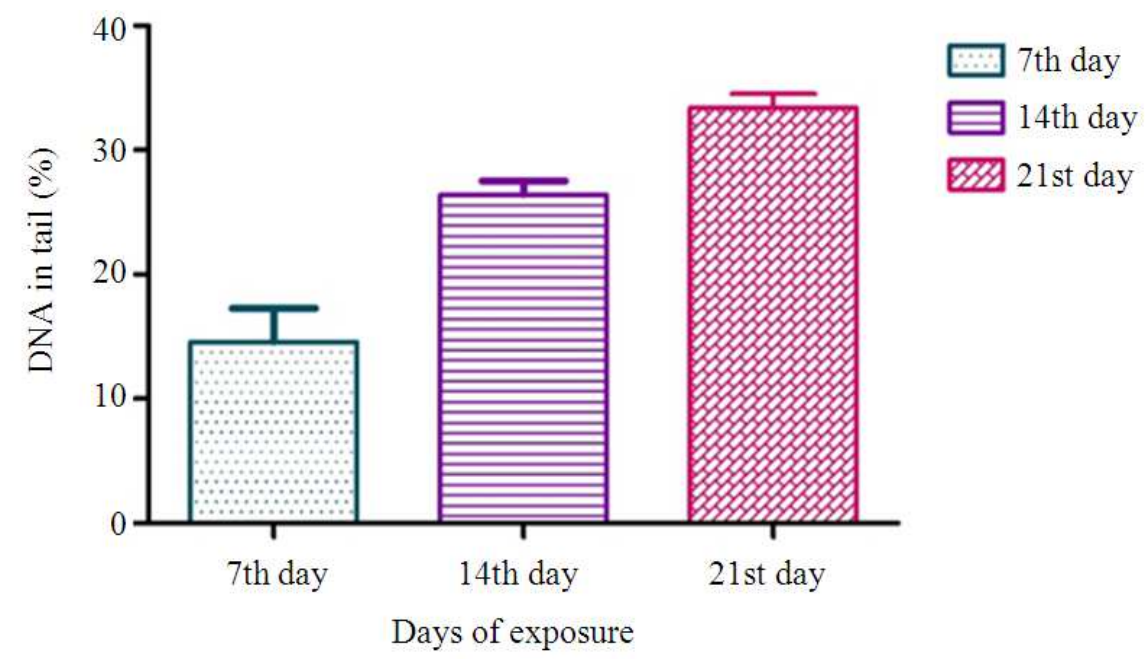

Fig. 5. Percentage of Tail DNA of Catla catla exposed to chromium at different Interval in Days

Table 5. Antioxidant enzyme responses observed in Catla catla exposed to sublethal concentration of potassium chromate

\begin{tabular}{lll}
\hline & CAT Activity in tissue $(\mu$ moles & SOD activity in tissue \\
of $\mathrm{H}_{2} \mathrm{O}_{2}$ consumed $/ \mathrm{min} / \mathrm{mg}$ of protein) & (U/mg protein) \\
Days of exposure & $\mathrm{Mean} \pm \mathrm{S} . \mathrm{D}$ & $6.25 \pm 0.35$ \\
\hline 7th day & $0.03 \pm 0.02$ & $5.37 \pm 0.74$ \\
14th day & $0.01 \pm 0.007$ & $4.27 \pm 1.42$ \\
\hline
\end{tabular}

The results are expressed as mean \pm SD. ${ }^{* *} \mathrm{p}<0.001$ for the significance of difference vs control (Mann-Whitney test) 


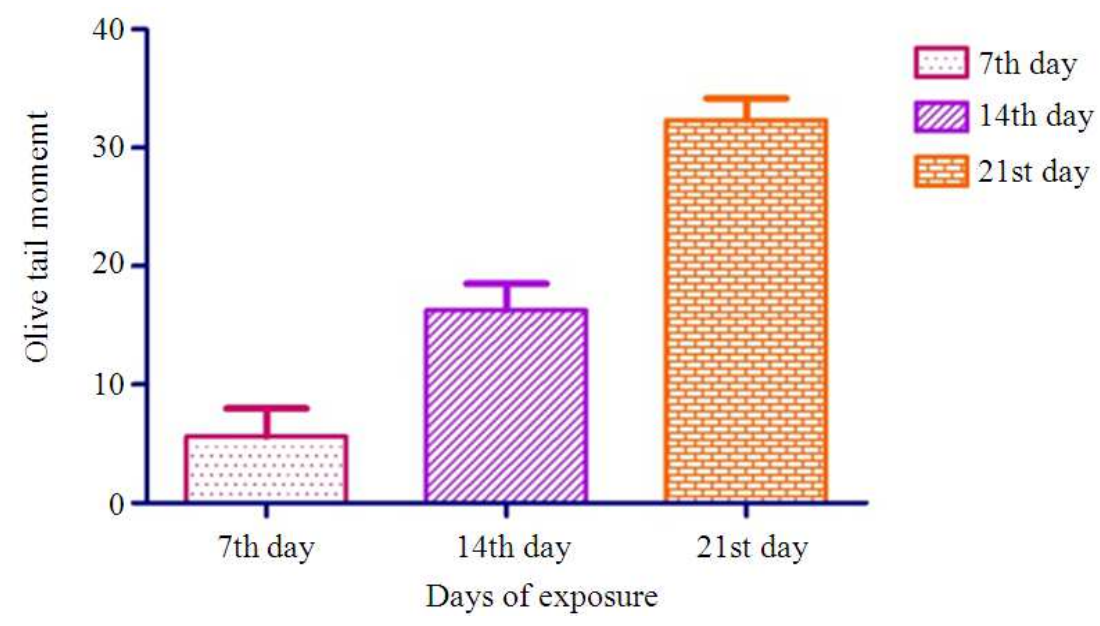

Fig. 6. Olive Tail Movement of catla catla exposed to chromium at different time interval in days

Table 6. Bioconcentration factors observed in Catla catla during sublethal toxicity study

\begin{tabular}{ll}
\hline Days of exposure & Bio Concentration Factor (BCF) \\
\hline 0th day & 0.011 \\
7th day & 2.534 \\
14th day & 3.173 \\
21st day & 3.504 \\
\hline
\end{tabular}

\subsection{Bio-concentration Factor Profile of Chromium in Catla Catla}

After the determination of mean concentrations of chromium in experimental water and fish, the bioconcentration factor values were calculated. The bioconcentration factor profiles of chromium in Catla catla during sublethal toxicity study are presented in Table 6, which shows that bio concentration factor values increases gradually through 21 days.

\section{CONCLUSION}

The micronucleus test and the comet assay are sensitive tools for the effective evaluation of genotoxicity biomarkers. The results of our experiments indicate an induction of micronuclei as well as other nuclear abnormalities, which were induced even if micronuclei were not; therefore, it is suggested to include these differences in fish genotoxicity analyses based on micronuclei counts. The results found in comet assay method and micronuclei test are in agreement with each other when compared at 21 days of exposure. At 21 days of chromium exposure both comet assay and micronucleus test revealed an increase in \% tail DNA and increased micronuclei frequency in all treatments studied. The results of this study showed the importance of fish liver as potential biomarker of chromium toxicity for comet assay. Our experimental data point out that Catla catla could be a suitable monitoring organism to study the bioavailability of water bound metals in freshwater habitats. It is also envisaged that features of oxidative stress could be used in aquatic pollution biomonitoring with varying degrees of specificity. Furthur studies are in progress to understand the underlying mechanisms involved in long-term toxicity profile of chromium in freshwater fish Catla catla. These genotoxic acessment along with the oxidative stress could be effectively used as potential non-specific biomarkers of heavy metal-toxicity to the freshwater fish in the field of environmental biomonitoring.

\section{ACKNOWLEDGEMENT}

The researchers greatly thankful to the SRM University for providing the infra-structure and lab facilities to carry out the research work and to the SRM Medical College for their timely help in conducting some experiments.

\subsection{Disclosure}

The authors declare no conflicts of interest in this study.

\section{REFERENCES}

Adeogun, A.O. and A.V. Chukwuka, 2012. Toxicity of industrial wastewater acting singly or in joint-ratios on clarias gariepinus. Am. J. Environ. Sci., 8: 366375. DOI: 10.3844/ajessp.2012.366.375 
Ali, D., N.S. Nagpure, S. Kumar, R. Kumar and B. Kushwaha et al., 2009. Assessment of genotoxic and mutagenic effects of chlorpyrifos in freshwater fish Channa punctatus (Bloch) using micronucleus assay and alkaline single-cell gel electrophoresis. Food Chem. Toxicol., 47: 650-656. PMID: 19141310

Ali, D., N.S. Nagpure, S. Kumar, R. Kumar and B. Kushwaha, 2008a. Genotoxicity assessment of acute exposure of chlorpyrifos to freshwater fish Channa punctatus (Bloch) using micronucleus assay and alkaline single-cell gel electrophoresis. Chemosphere, 71: 1823-1831. DOI: 10.1016/j.chemosphere.2008.02.007

Ali, F.K., A.M. El-Shehawi and M.A. Seehy, 2008b. Micronucleus test in fish genome: A sensitive monitor for aquatic pollution. Afr. J. Biotechnol., 7: 606-612.

Alkassasbeh, J.Y.M., L.Y. Heng, S. Surif and U.K.M. Bangi, 2009. Toxicity testing and the effect of landfill leachate in malaysia on behavior of common carp (Cyprinus Carpio L., 1758; Pisces, Cyprinidae). Am. J. Environ. Sci., 5: 209-217. DOI: 10.3844/ajessp.2009.209.217

Al-Sabti, K. and C.D. Metcalfe, 1995. Fish micronuclei for assessing genotoxicity in water. Mutat. Res., 343: 121-135. DOI: 10.1016/0165-1218(95)90078-0

Al-Yousuf, M.H., M.S. El-Shahawi and S.M. Al-Ghais, 2000. Trace metals in liver, skin and muscle of Lethrinus lentjan fish species in relation to body length and sex. Sci. Total Environ., 256: 87-94. DOI: $10.1016 / \mathrm{S} 0048-9697(99) 00363-0$

Anbumani, S. and M.N. Mohankumar, 2012. Gamma radiation induced micronuclei and erythrocyte cellular abnormalities in the fish Catla catla. Aquat. Toxicol., 122-123: 125-132. PMID: 22771702

Anitha, B., N. Chandra, P.M. Gopinath and G. Durairaj, 2000. Genotoxicity evaluation of heat shock in gold fish (Carassius auratus). Mutat. Res., 469: 1-8. PMID: 10946237

Avishai, N., C. Rabinowitz and B. Rinkevich, 2003. Use of the comet assay for studying environmental genotoxicity: Comparisons between visual and image analyses. Environ. Mol. Mutagen., 42: 155165. PMID: 14556223

Ayllon, F. and E. Garcia-Vazquez, 2000. Induction of micronuclei and other nuclear abnormalities in European minnow Phoxinus phoxinus and mollie Poecilia latipinna: an assessment of the fish micronucleus test. Mutat. Res., 467: 177-186. PMID: 10838205
Balachandar, V., M. Arun, M.S. Devi, P. Velmurugan and P. Manikantan et al., 2010. Evaluation of the genetic alterations in direct and indirect exposures of hexavalent chromium $[\mathrm{Cr}(\mathrm{VI})]$ in leather tanning industry workers North Arcot District, South India. Int. Arch. Occup. Environ. Health 83: 791-801. PMID: 20617332

Bolognesi, C. and M. Hayashi, 2011. Micronucleus assay in aquatic animals. Mutagenesis, 26: 205-213. DOI: 10.1093/mutage/geq073, PMID: 21164204

Bucker, A., M. Carvalho, M. Conceicao and J. AlvesGomes, 2012. Micronucleus test and comet assay in erythrocytes of the Amazonian electric fish Apteronotus bonapartii exposed to benzene. J. Brazilian Soc. Ecotoxicol., 7: 65-73.

Cavallo, D., C.L. Ursini, B. Rondinone and S. Iavicoli, 2009. Evaluation of a suitable DNA damage biomarker for human biomonitoring of exposed workers. Environ. Mol. Mutagen., 50: 781-790. PMID: 19449396

Cavas, T., N.N. Garanko and V.V. Arkhipchuk, 2005. Induction of micronuclei and binuclei in blood, gill and liver cells of fishes subchronically exposed to cadmium chloride and copper sulphate. Food Chem. Toxicol., 43: 569-574. PMID: 15721204

Company, R., A. Serafim, R.P. Cosson, A. FialaMedioni and L. Camus et al., 2010. Sub-lethal effects of cadmium on the antioxidant defence system of the hydrothermal vent mussel Bathymodiolus azoricus. Ecotoxicol. Environ. Saf., 73: 788-795. PIMD: 20137812

De Andrade, V.M., T.R.O. De Freitas and J. Da Silva, 2004. Comet assay using mullet (Mugil sp.) and sea catfish (Netuma sp.) erythrocytes for the detection of genotoxic pollutants in aquatic environment. Mutat. Res., 560: 57-67. PMID: 15099825

Dede, E.B. and E.D. Kaglo, 2001. Aqua-toxicological Effects of Water Soluble Fractions (WSF) of diesel fuel on $O$. Niloticus fingerlings. J. Applied Sci. Environ. Mgt., 5: 93-96.

Ellis, A.S., T.M. Johnson and T.D. Bullen, 2002. Chromium isotopes and the fate of hexavalent chromium in the environment. Science, 295: 20602062. PMID: 11896274

Emmanouil, C., D.J. Smart, N.J. Hodges and J.K. Chipman, 2006. Oxidative damage produced by $\mathrm{Cr}(\mathrm{VI})$ and repair in mussel (Mytilus edulis L.) gill. Mar. Environ. Res., 62: S292-S296. PMID: 16698074 
Eyckmans, M., N. Celis, N. Horemans, R. Blust and D.G. Boeck, 2011. Exposure to waterborne copper reveals differences in oxidative stress response in three freshwater fish species. Aquat. Toxicol., 103: 112-120. PMID: 21419094

Fatemi, S.J.A., M. Iranmanesh and F.D. Balooch, 2013. Effect of Chromium(VI) on serum iron and removal of its toxicity by combining deferasirox and deferiprone chelators in rats. Am. J. Pharmacol. Toxicol., 8: 164169. DOI: $10.3844 /$ ajptsp.2013.164.169

Finney, D.J., 1971. Probit Analysis. 1st Edn., Cambridge University Press, Cambridge, ISBN-10: 0521135907, pp: 272.

Fontanetti, C.S., C.A. Christofoletti, T.G. Pinheiro, T.S. Souza and J. Pedro-Escher, 2010. Microscopy as a tool in toxicological evaluations. University Estadual Paulis.

Foster, W.J., A.D.E. Chatelet and M. Rogerson, 2012. Testing benthic foraminiferal distributions as a contemporary quantitative approach to biomonitoring estuarine heavy metal pollution. Mar. Pollut. Bull., 64: 1039-1048. DOI: 10.1016/j.marpolbul.2012.01.021

Garg, S., R.K. Gupta and K.L. Jain, 2009. Sublethal effects of heavy metals on biochemical composition and their recovery in Indian major carps. J. Hazard. Mater., 163: 1369-1384. PMID: 18775601

Gheju, M., 2011. Hexavalent Chromium Reduction with Zero-Valent Iron (ZVI) in Aquatic Systems. Water, Air, Soil Pollut., 222: 103-148. DOI: 10.1007/s1 1270-011-0812-y

Hartmann, A., 1997. The contribution of cytotoxicity to DNA-effects in the single cell gel test (comet assay). Toxicol. Lett., 90: 183-188. PMID: 9067486

Hernández, P.P., V. Moreno, F.A. Olivari and M.L. Allende, 2006. Sub-lethal concentrations of waterborne copper are toxic to lateral line neuromasts in zebrafish (Danio rerio). Hear. Res., 213: 1-10. PMID: 16386394

Heuser, V.D., D.J. Silva, H.J. Moriske, J.F. Dias and M.L. Yoneama et al., 2002. Genotoxicity biomonitoring in regions exposed to vehicle emissions using the comet assay and the micronucleus test in native rodent Ctenomys minutus. Environ. Mol. Mutagen., 40: 227-235. PMID: 12489112

Jomova, K. and M. Valko, 2011. Advances in metalinduced oxidative stress and human disease. Toxicology, 283: 65-87. PMID: 21414382
Kim, B.S., J.J. Park, L. Edler, V.D. Fournier and W. Haase et al., 2002. New measure of DNA repair in the single-cell gel electrophoresis (comet) assay. Environ. Mol. Mutagen., 40: 50-6. PMID: 12211076

Klobucar, G.I.V., O. Malev, M. Srut, A. Stambuk and S. Lorenzon et al., 2012. Genotoxicity monitoring of freshwater environments using caged crayfish (Astacus leptodactylus). Chemosphere, 87: 62-67. PMID: 22178377

Kubrak, O.I., V.V. Husak, B.M. Rovenko, J.M. Storey and K.B. Storey et al., 2011. Cobalt-induced oxidative stress in brain, liver and kidney of goldfish Carassius auratus. Chemosphere, 85: 983-999. PMID: 21777937

Kumar, S., R. Budhwar, A. Nigam and S. Priya, 2009. Cytoprotection against $\mathrm{Cr}(6+)$-induced DNA damage by alpha-lipoic acid: Implications in reducing occupational cancer risk. Mutagenesis, 24: 495-500. PMID: 19710206

Kumaravel, T.S. and A.N. Jha, 2006. Reliable Comet assay measurements for detecting DNA damage induced by ionising radiation and chemicals. Mutat. Res., 605: 7-16. PMID: 16621680

Lavanya, S., M. Ramesh, C. Kavitha and A. Malarvizhi, 2011. Hematological, biochemical and ionoregulatory responses of Indian major carp Catla catla during chronic sublethal exposure to inorganic arsenic. Chemosphere, 82: 977-985. PMID: 21094981

Mendil, D., O.F. Unal, M. Tuzen and M. Soylak, 2010. Determination of trace metals in different fish species and sediments from the River Yesilirmak in Tokat, Turkey. Food Chem. Toxicol., 48: 13831392. DOI: $10.1016 /$ j.fct.2010.03.006

Mishra, A.K. and B. Mohanty, 2008. Acute toxicity impacts of hexavalent chromium on behavior and histopathology of gill, kidney and liver of the freshwater fish, Channa punctatus (Bloch). Environ. Toxicol. Pharmacol., 26: 136-141. DOI: 10.1016/j.etap.2008.02.010

Mortazavi, S.B., A. Safari, A. Khavanin, A. Kazemnejad and S.M. Moazzeni et al., 2005. Induction of micronuclei in mice lymphocytes exposed to microwave and toluene. Am. J. Applied Sci., 2: 1321-1324. DOI: 10.3844/ajassp.2005.1321.1324

Muid, K.A., R.M. Shahjahan, R. Begum and R.A. Begum, 2012. Zinc phosphide induced DNA damage in the blood cells of Gallus sp. using comet DNA assay. Am. J. Agric. Biol. Sci., 7: 82-87. DOI: 10.3844/ajabssp.2012.82.87 
Nickens, K.P., S.R. Patierno and S. Ceryak, 2010. Chromium genotoxicity: A double-edged sword. Chem. Biol. Interact., 188: 276-288. PMID: 20430016

Oyoo-Okoth, E., W. Admiraal, O. Osano, V. Ngure and M.H.S. Kraak et al., 2010. Monitoring exposure to heavy metals among children in Lake Victoria, Kenya: Environmental and fish matrix. Ecotoxicol. Environ. Saf., 73: 1797-1803. PMID: 20705339

Palaniappan, P.R. and S. Karthikeyan, 2009. Bioaccumulation and depuration of chromium in the selected organs and whole body tissues of freshwater fish Cirrhinus mrigala individually and in binary solutions with nickel. J. Environ. Sci., 21: 229-236. DOI: 10.1016/S1001-0742(08)62256-1

Palus, J., K. Rydzynski, E. Dziubaltowska, K. Wyszynska and A. Natarajan et al., 2003. Genotoxic effects of occupational exposure to lead and cadmium. Mutat. Res. Toxicol. Environ. Mutagen., 540: 19-28. PMID: 12972055

Polard, T., S. Jean, G. Merlina, C. Laplanche and E. Pinelli et al., 2011. Giemsa versus acridine orange staining in the fish micronucleus assay and validation for use in water quality monitoring. Ecotoxicol. Environ. Saf., 74: 144-119. PMID: 20828819

Quievryn, G., E. Peterson, J. Messer and A. Zhitkovich, 2003. Genotoxicity and mutagenicity of chromium(VI)/ascorbate-generated DNA adducts in human and bacterial cells. Biochemistry, 42: 10621070. PMID: 12549927

Quinn, B., F. Gagne, C. Blaise, M.J. Costello and J.G. Wilson et al., 2006. Evaluation of the lethal and sublethal toxicity and potential endocrine disrupting effect of nonylphenol on the zebra mussel (Dreissena polymorpha). Comp. Biochem. Physiol. C. Toxicol. Pharmacol., 142: 118-127. PMID: 16377254

Rao, G.T., V.V.S.G. Rao, K. Ranganathan, L. Surinaidu and J. Mahesh et al., 2011. Assessment of groundwater contamination from a hazardous dump site in Ranipet, Tamil Nadu, India. Hydrogeol. J., 19: 1587-1598. DOI: 10.1007/s10040-011-0771-9
Rojas, E., M.C. Lopez and M. Valverde, 1999. Single cell gel electrophoresis assay: Methodology and applications. J. Chromatogr. B. Biomed. Sci. Applic., 722: 225-254. PMID: 10068143

Sayeed, I., S. Parvez, S. Pandey, B. Bin-Hafeez and R. Haque et al., 2003. Oxidative stress biomarkers of exposure to deltamethrin in freshwater fish, Channa punctatus Bloch. Ecotoxicol. Environ. Saf., 56: 295301. PMID: 12927561

Schmid, W., 1975. The micronucleus test. Mutat. Res., 31: 9-15. PMID: 48190

Sinha, A.K., 1972. Colorimetric assay of catalase. Anal. Biochem., 47: 389-394. DOI: 10.1016/00032697(72)90132-7

Sun, Y., H. Yu, J. Zhang, Y. Yin and H. Shen et al., 2006. Bioaccumulation and antioxidant responses in goldfish Carassius auratus under HC Orange No. 1 exposure. Ecotoxicol. Environ. Saf., 63: 430-437. PMID: 16406596

Tice, R.R., E. Agurell, D. Anderson, B. Burlinson and A. Hartmann et al., 2000. Single cell gel/comet assay: Guidelines for in vitro and in vivo genetic toxicology testing. Environ. Mol. Mutagen., 221: 206-221. PMID: 10737956

Velma, V. and P.B. Tchounwou, 2010. Chromiuminduced biochemical, genotoxic and histopathologic effects in liver and kidney of goldfish, Carassius auratus. Mutat. Res., 698: 43-51. PMID: 20348018

Yadav, K.K. and S.P. Trivedi, 2009. Sublethal exposure of heavy metals induces micronuclei in fish, Channa punctata. Chemosphere, 77: 1495-1500. PMID: 19880156

Yilmaz, A.B., M.K. Sangun, D. Yaglioglu and C. Turan, 2010. Metals (major, essential to non-essential) composition of the different tissues of three demersal fish species from Iskenderun Bay, Turkey. Food Chem., 123: 410-415. DOI: 10.1016/j.foodchem.2010.04.057

Zhou, Q., J. Zhang, J. Fu, J. Shi and G. Jiang, 2008. Biomonitoring: An appealing tool for assessment of metal pollution in the aquatic ecosystem. Anal. Chim. Acta, 606: 135-150. PMID: 18082645 